\title{
REVIEW
}

\section{TRH-Like Peptides}

\author{
R. BÍLEK ${ }^{1}$, M. BIČÍKOVÁ ${ }^{1}$, L. ŠAFAŘÍK ${ }^{2}$ \\ ${ }^{1}$ Institute of Endocrinology, Prague, Czech Republic, ${ }^{2}$ Urology Clinic, Beroun, Czech Republic
}

Received September 6, 2010

Accepted October 8, 2010

On-line November 29, 2010

\begin{abstract}
Summary
TRH-like peptides are characterized by substitution of basic amino acid histidine (related to authentic TRH) with neutral or acidic amino acid, like glutamic acid, phenylalanine, glutamine, tyrosine, leucin, valin, aspartic acid and asparagine. The presence of extrahypothalamic TRH-like peptides was reported in peripheral tissues including gastrointestinal tract, placenta, neural tissues, male reproductive system and certain endocrine tissues. Work deals with the biological function of TRH-like peptides in different parts of organisms where various mechanisms may serve for realisation of biological function of TRH-like peptides as negative feedback to the pituitary exerted by the TRH-like peptides, the role of pEEPam such as fertilization-promoting peptide, the mechanism influencing the proliferative ability of prostatic tissues, the neuroprotective and antidepressant function of TRH-like peptides in brain and the regulation of thyroid status by TRH-like peptides.
\end{abstract}

\section{Key words}

TRH • TRH-like peptides • Extrahypothalamic occurrence • Biological function

\section{Corresponding author}

R. Bílek, Institute of Endocrinology, Národní 8, 11694 Prague 1, Czech Republic. E-mail: rbilek@endo.cz

\section{Introduction}

Thyrotropin-releasing hormone (TRH), a major hypothalamic factor in regulation of thyrotropin (TSH) secretion, was the first chemically defined hypophyseotropic hormone (Boler et al. 1969, Schally et al. 1969, Burgus et al. 1970). It is worth noting that one of the leaders working in the area concerning the TRH research was Professor V. Schreiber from Prague, Czech Republic, which already in 1959 formulated the hypothesis that adenohypophyseal acid phosphatase is related to thyrotropin secretion and that TRH is its possible activator (Schreiber and Kmentova 1959, Schreiber et al. 1962). TRH precursor, human prepro$\mathrm{TRH}$, consists of 242 amino acid residues, and contains six separate copies of the TRH progenitor sequence (Satoh and Mori 1994), which determine the primary structure of TRH as a tripeptide pyroglutamyl-histidinylproline amide. The transcriptional unit of prepro-TRH is localized on chromosome 3 in humans (three exons interrupted by two introns) (Yamada et al. 1990).

TRH-like peptides are related to TRH. These peptides are characterized by substitution of basic amino acid histidine (related to authentic TRH) for neutral or acidic amino acids (Pekary et al. 1983). The presence of TRH-immunoreactive peptides was reported not only in the hypothalamus, but also in peripheral tissues including the prostate gland and male reproductive system, retina, placenta, gastrointestinal tract, neural (brain) and certain endocrine tissues including pituitary, Langerhans' islets, thyroid and adrenal gland (Bilek 2000). TRH immunoreactivity corresponding to TRH-like peptides were detected also in the mammary gland and the milk (Ghilchik et al. 2000).

To 1995, four TRH-like peptides were identified and characterized by having their central amino acid histidine (related to authentic TRH) exchanged for glutamic acid (Cockle et al. 1989a,b), phenylalanine (Khan et al. 1992, Gkonos et al. 1994), glutamine (Khan et al. 1992), or tyrosine (Lackey 1992, Pekary et al. 2005). Recently additional TRH-like peptides were 


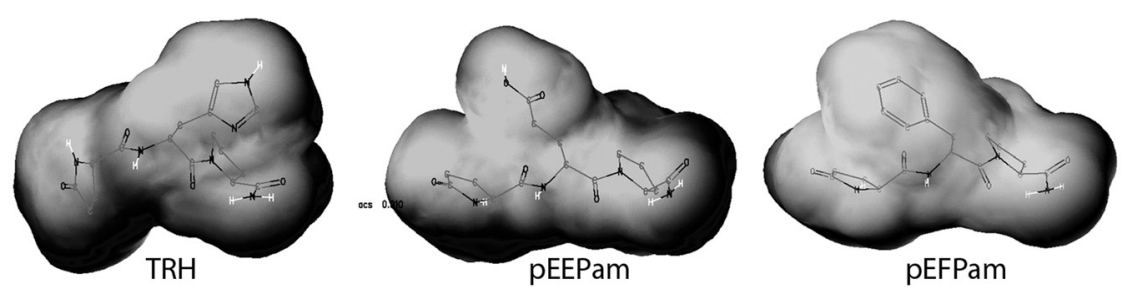

Fig. 1. Spatial structures of TRH and TRHlike peptides pGLU-GLU-PRO. NH2 (pEEPam) pGLU-PHE-PRO.NH2 (pEFPam) created using the modeling program Cache 7.5, Fujitsu Lim., Japan. discovered in brain, where histidin of TRH was exchanged for leucin or valin (Pekary and Sattin 2001, Hinkle et al. 2002), or in testis where histidin of TRH was exchanged for aspartic acid or asparagine (RuizAlcaraz and Del Rio-Garcia 2005). An N-extended form of TRH-like peptides was observed in substantial concentration in human plasma (Ruiz-Alcaraz and del Rio-Garcia 2003) or in human semen (Khan and Smyth 1993). The analysis of rabbit prostate and testis have shown that in contrast to the prostate, testis contains high concentrations of N-extended form of pEFPam, but essentially no tripeptide (Linden et al. 1996). Similar results were found in human testis and prostate (Bilek et al. 1994). It emerges from these papers that the authentic TRH and extrahypothalamic TRH-like peptides have primary structures pyroGLU-HIS-PRO. $\mathrm{NH}_{2}$ (TRH), pyroGLU-ASP-PRO.NH $\mathrm{NH}_{2}$ (pEDPam), pyroGLU-ASNPRO. $\mathrm{NH}_{2}$ (pENPam), pyroGLU-GLU-PRO.NH (pEEPam), pyroGLU-GLN-PRO. $\mathrm{NH}_{2}$ (pEQPam),

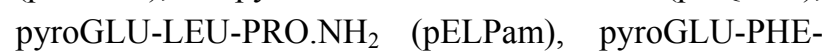
PRO. $\mathrm{NH}_{2}$ (pEFPam), pyroGLU-TYR-PRO.NH (pEYPam), and pyroGLU-VAL-PRO.NH $\mathrm{NH}_{2}$ (pEVPam), respectively. TRH-like peptides possess a C-terminal amide group which is characteristic for many biologically active peptides. The actual research is targeted mainly on pEEPam and pEFPam, which may be most important members of TRH-like peptides. TRH-like peptides cannot be expressed from the TRH gene and mechanism of their expression is not known.

\section{Interaction of TRH-like peptides with TRH receptors}

TRH cell-surface receptors type 1 (TRH-R1) and type 2 (TRH-R2) have been cloned from mammals. They belong to the superfamily of $G$ protein-coupled receptors. These receptors are distributed differently in the brain and peripheral tissues, but exhibit indistinguishable binding affinities for TRH and TRH analogs. Although they both can be stimulated by TRH to similar maximal signaling levels, TRH-R2 exhibits higher basal signaling activity and is more rapidly internalized than TRH-R1
(Sun et al. 2003). TRH-R2 was isolated from rat brain cDNAs. Northern blot analysis with TRH-R2 probe revealed brain-specific expression of a $9.5 \mathrm{~kb}$ mRNA (Itadani et al. 1998). Consistent expression was found for both receptors, TRH-R1 and TRH-R2, also in rat thyroid gland (De Miguel et al. 2005). For now, this type of receptor (TRH-R2) was found only in rat and mouse, not in human.

TRH-R1 specific mRNA was detected in most of the peripheral tissues tested, and it may be suggested that TRH-R1 has specific functions in these tissues (Fukusumi et al. 1995), mainly because the half-time of TRH in circulation is only 6.5 minutes in euthyroid subjects (Iversen 1991). Human TRH-R1 is a $45 \mathrm{kDa}$, 398 amino acids, 7 helices transmembrane G-protein coupled glycoprotein receptor, which activates the phosphatidylinositol-calcium-protein kinase C transduction pathway after the interaction with TRH. The gene responsible for its expression is localized in the long arm of human chromosome 8 (cytogenetic band 8q23) (Morrison et al. 1994). Human TRH-R1 belongs to an extensive group 1 (rhodopsin-like) of G-protein coupled receptors with structure according Swiss Institute of Bioinformatic and European Bioinformatics Institute (Swiss-Prot entry, accession number P34981,) which consists of seven transmembrane regions linked with three extracellular and three intracellular loops. The glycosylated N-terminus is placed on the extracellular side of the membrane and a potentionally phospohorylated C-terminal end is found in a cytoplasmatic membrane site.

The basic question is whether TRH-like peptides can interact with TRH-R1 and TRH-R2. Multiple computational methods have been employed in a comparative study of TRH-R1 and TRH-R2. Using de novo modeling procedures of human TRH-R1 (G-protein coupled receptors model) on an automated protein modeling server at the Glaxo Wellcome Experimental Research, Geneva, Switzerland, no direct evidence is that TRH-like peptides can interact with the presented human TRH-R1 model. On the contrary, with respect to the similar 3D-shape and the identity of terminal amino 


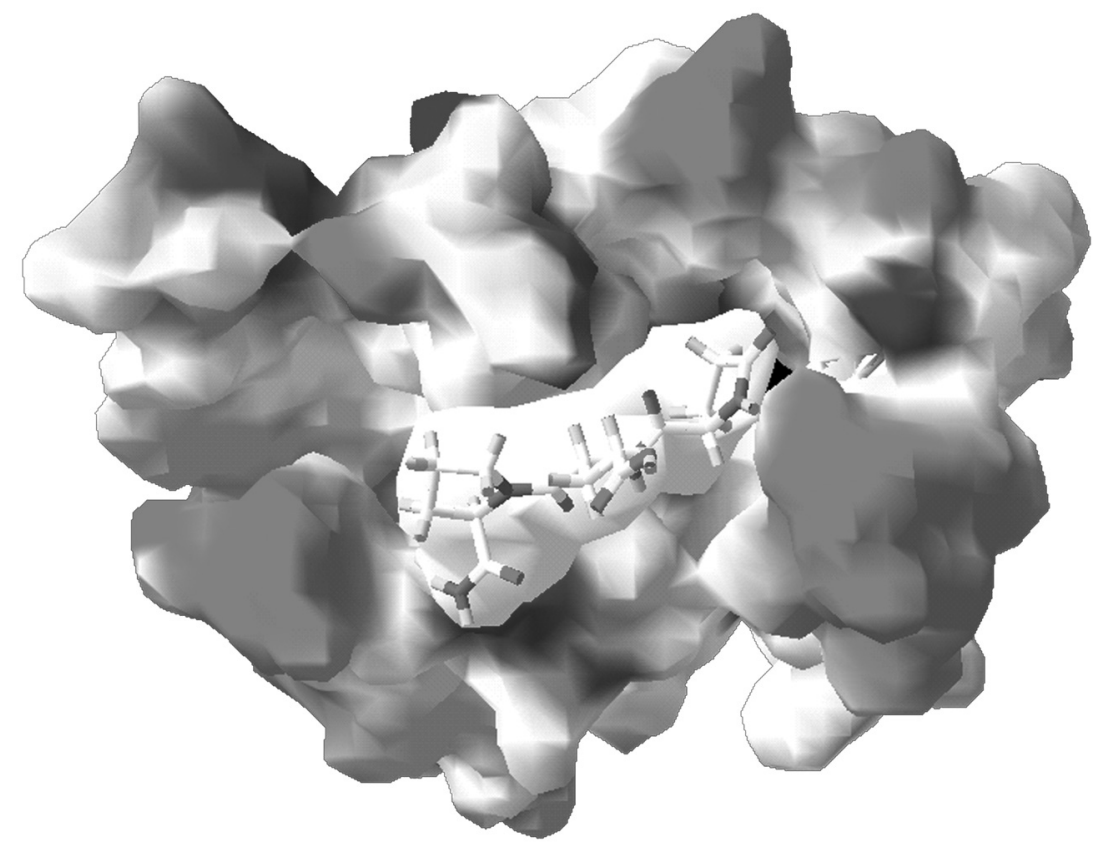

Fig. 2. Three-dimensional computer model of interaction between transmembrane domains of human TRH receptor type 1 and pEEPam. The model was generated using de novo modeling procedures of human TRH-R1 (G-protein coupled receptors model) on an automated protein modeling server at the Glaxo Wellcome Experimental Research, Geneva, Switzerland and using modeling program Cache 7.5, Fujitsu Lim., Japan.

acids, it appears that these interactions are highly probable as well as the nearly $100 \%$ cross-reactions between TRH or TRH-like peptides and antibody specific against authentic TRH (Bilek and Starka 2005). This assumption can be suported by experiments used to characterize TRH binding sites in rat brain cortex. Replacement of $\left[{ }^{3} \mathrm{H}\right][3-$ Methyl-His $] \mathrm{TRH}$ from single population of high-affinity, low-capacity binding sites in cortex by peptides, in which the histidyl residue of TRH was systematically replaced by a series of 24 natural and unnatural amino acids, showed that values of interaction constant varied from $10^{-3}$ to $10^{-9} \mathrm{~mol} / 1$ and the potency order was: [ $\left.{ }^{3} \mathrm{H}\right][3-$ Methyl-His2]TRH >His $>$ Leu,Phe, Asn $>$ Gln, Arg, Thr, Ala (Kelly et al. 2002). It was also reported that $\mathrm{TRH}$-like peptides bind with high affinity to TRH-R2 in rat brain, and that this receptor acts as the transducer for some of the CNS effects. pEEPam, pEVPam and pELPam were analeptics, like TRH, but pEFPam and pEYPam were not (Hinkle et al. 2002).

\section{TRH-like peptides in reproductive tissues}

The research of TRH-like peptides is concentrated mainly to the male reproductive tissues. In rat prostate only TRH-like peptides are present (Bilek et al. 1992). According to our previous experiments, we assume the existence of a local hormonal network formed by TRH-like peptides and TSH in the prostate gland. The network can be associated with circulating thyroid and steroid hormones, and may represent a new regulatory mechanism influencing the proliferative ability of prostatic tissue. This is in the concordance with our former experiments where the concentration of prostatic TRH-like peptides was sensitive to circulating thyroid and steroid hormones (Bilek et al. 1992, Bílek et al. 1996). The main hormonal influence acting upon the prostate is exerted by androgens, but androgens alone are not sufficient for inducing normal or pathological growth and function of the prostate. The decline of testicular function, which is detectable in men over fifty years old, introduces a disbalance into the paracrine or autocrine production of various growth factors influencing the prostate. Androgens may exert their effect on the prostate by regulating the synthesis of growth factors. It could be supposed that sufficient level of androgens is able to suppress the production of prostatic growth factors, and vice versa. Following disbalance, the synthesis of growth factors is induced some way. It seems to be compatible with the fact that the number of patients with benign or malignant prostatic disease increases with age and it is accompanied with a decline of androgens. Our understanding, which is based on our results concerning experiments with the prostatic gland, supposes that there might be an important connection of TRH-like peptides to the prostatic local autocrine/paracrine network mediated by extrahypothalamic TRH immunoreactivity corresponding to TRH-like peptides, and extrapituitary thyrotropin (TSH) immunoreactivity also found in the prostatic tissue. A similar system of intraepithelial lymphocyte hormonal regulation due to the local paracrine network of TRH/TSH has been described in the gastrointestinal tract (Shanahan 1997, Wang et al. 1997), 
where the extrahypothalamic TRH reacts with receptors on enterocytes, which is followed by thyrotropin (TSH) expression. TSH is bound to specific receptors on intraepithelial lymphocytes and cast an influence on their maturation. It may be suggested that the role of TRH, which is not present in a prostate gland could be overtaken by prostatic TRH-like peptides, particularly when the endocrine cells of the prostate also produce TSH in addition to TRH-like peptides (Abrahamsson and Lilja 1989). The prostatic gland is most commonly affected by benign prostatic hyperplasia or prostatic cancer. They pose a difficult medical and socialeconomical problem regarding their high prevalence mainly among men over fifty years old. The expectant local prostatic network of TRH-like peptides/TSH may bring new possibilities of regulation mechanisms in proliferation of the prostate gland.

In rat testis have been identified by chromatography and mass spectrometry pEEPam, pEDPam, pENPam, pEQPam, pEFPam and pEYPam. A subcutaneous administration of the pEEPam, pEQPam pEFPam were able to reduce plasma levels of testosterone and luteinizing hormone (LH) without modification of the levels of follicle stimulating hormone (FSH). Administration of pEDPam resulted in an increase of plasmatic testosterone without modifying LH or FSH levels. Authors (Ruiz-Alcaraz and Del Rio-Garcia 2005) suppose that TRH-like peptides which reduce the concentrations of testosterone and LH are released from the testis and act in the pituitary due to circulation in an endocrine manner. The specific inhibition of $\mathrm{LH}$ release is similar to that produced by inhibin on FSH release. pEDPam which increases the levels of testosterone is produced in the testis and seems to act directly in the testis in a paracrine or autocrine manner. The above mentioned authors proposed the generic name of gonadins for the novel family of TRH-like peptides.

pEEPam has been named fertilization-promoting peptide because of its ability to enhance the in vitro fertilizing potential of mouse epididymal spermatozoa (Cockle et al. 1994). The peptide was found in the seminal plasma of several mammalian species and it stimulates mouse and human sperm capacitation and fertilizing ability in vitro (Green et al. 1996a). Supposed mechanism is that pEEPam may act by modulating the adenylate cyclase/cyclic AMP signal transduction pathway (Green et al. 1996b). pEEPam was the predominant TRH-like peptide in epididymis, and pEEPam concentration in the epididymis of male rats increased 3-fold after treatment with valproate (Pekary et al. 2006d), or 3- to 25-fold after i.p. administration of escitalopram which is a highly selective serotonin reuptake inhibitor (Sattin et al. 2008).

\section{TRH-like peptides in central nervous system (CNS)}

TRH exerts multiple CNS-mediated actions that can have therapeutic potential in treating a wide range of neurological disorders. The clinical use of TRH are hindered due to its rapid degradation by TRH-degrading ectoenzyme (Scalabrino et al. 2007). TRH and TRH-like peptides have neuroprotective, antidepressant, antiepileptic, analeptic, arousal, anti-ataxic, and anorectic properties that could mediate the neuropsychiatric and therapeutic effects of a variety of neurotropic agents (Sattin et al. 2008, Pekary et al. 2010). High pressure liquid chromatography revealed that in many brain regions TRH immunoreactivity was observed which was consisted of a mixture of TRH and other TRH-like peptides including pEEPam, pEVPam, pEYPam, pELPam and pEFPam (Pekary and Sattin 2001). The synthesis and release of $\mathrm{TRH}$, and other neurotropic TRH-like peptides was mediated by some of the mood stabilizing effects of valproate which facilitates the synthesis of TRH-like peptides in rat brain (Pekary et al. 2006d). Both pEEPam and pEFPam produced significant antidepressant effects, with pEEPam producing the stronger response (Lloyd et al. 2001). Neuropsychiatric illness can be associated with abnormalities of glucocorticoid concentrations in circulation. Endogenous antidepressant-like properties of TRH and TRH-like peptides can be connected with their ability to mediate or modulate the acute effects of corticosterone administration in rats (Pekary et al. 2008). Significant increases, ranging from 2- to 12-fold, in TRH or TRHlike peptide levels were observed in almost all brain regions studied at $4 \mathrm{~h}$ after corticosterone injection $(4 \mathrm{mg})$ to male rats (Pekary et al. 2006c).

TRH together with pEEPam were found to be neuroprotective in vitro against an excitotoxic insult of glutamate-induced toxicity. Even though pEEPam was as much as four times more neuroprotective than TRH, its ability to reduce glutamate-stimulated increases in intraneuronal $\mathrm{Ca}^{2+}$ was about half that of TRH (Koenig et al. 2001). Lipopolysaccharide is a proinflammatory and depressogenic agent which can modulate the expression and release of TRH and TRH-like peptides. 
Intraperitoneal injection of lipopolysaccharide to male rats resulted in TRH declined and TRH-like peptides have decreased release and clearance in various areas of brain that coordinates the behavioral, endocrine, and immune responses to the stresses of sickness, injury, and danger (Pekary et al. 2007).

pEEPam administered intravenously in its CNSpermeable prodrug forms exerted analeptic action in antagonizing pentobarbital-induced narcosis of mice (Prokai-Tatrai et al. 2005). The acute effect after administration of escitaloprame (serotonine reuptake inhibitor) in rat brain regions involved in mood regulation was to increase the levels of TRH-like peptides, most consistently pEFPam. Some of the therapeutic effects of inhibition of serotonin reuptake can therefore be mediated by altered release of TRH and TRH-like peptides (Sattin et al. 2008).

Abnormal hyperphosphorylation of the microtubule associated protein tau is a hallmark of Alzheimer disease and related diseases called tauopathies (Alonso et al. 2010). Glycogen synthase kinase-3beta is an enzyme that hyperphosphorylates protein tau and is implicated in bipolar disorder, diabetes and Alzheimer's disease. TRH reduces the expression of glycogen synthase kinase-3beta and injections of glycogen synthase kinase-3beta inhibitor to male rats resulted in large (3-15 fold) increases of TRH and TRH-like peptide levels in brain during short period (hours). In contrast, a nearly complete loss of TRH and TRH-like peptides was observed from testis and pancreas (Pekary et al. 2010).

The centrally active pELPam showed a significant increase in the extracellular acetylcholine concentration during its perfusion to the hippocampus in rats in much smaller quantities compared to TRH (Prokai and Zharikova 2002). pEEPam also opposes the cholinergic effect of TRH in the mammalian central nervous system (Nguyen et al. 2007).

Significant decreases of TRH and TRH-like peptides were found in brain after injection $(1 \mathrm{mg} / \mathrm{kg})$ of leptin to male rats (Pekary et al. 2010). There can be the association among leptin, TRH-like peptides and thyroid hormones due to modulation of 5'-deiodinases in different tissues, depending on energetic status of organism.

\section{TRH-like peptides in thyroid gland}

It has been demonstrated that rat thyroid C-cells express authentic TRH, affecting thyroid hormone secretion by follicular cells, which also showed consistent expression for both receptors, TRH-R1 and TRH-R2. It can be novel intrathyroidal regulatory pathway of thyroid hormone secretion via paracrine/autocrine TRH signaling (De Miguel et al. 2005). Human thyroid was shown to contain both authentic TRH and TRH-like peptides, a similar pattern was seen in a range of animal thyroids (Smyth et al. 1999). Subcutaneous administration of pEEPam or pEFPam in male and female mice led to increased levels of triiodothyronine (T3) and to a lesser extent tetraiodothyronine (T4) in the circulation. pEFPam was more potent than pEEPam with similar potency as TRH. pEFPam, pEEPam and TRH produced significantly greater effects in the female than in the male (Cremades et al. 1998). pEFPam can crossreact with the TRH receptor and this TRH-like peptide significantly increase serum T3 (Lloyd et al. 2001). Transition of male rats from the hyperthyroid to the hypothyroid state increased the pEVPam and pEYPam levels in the accumbens by 10 -fold and 15-fold, and in the pyriform cortex by 9-fold and 12-fold, respectively. Hypothyroidism and castration reduced the levels of TRH and the majority of other TRH-like peptides in the entorhinal cortex (Pekary and Sattin 2001).

Thyroid hormones have influence to TRH-like pepides in brain, because rapid increases or decreases in TRH and TRH-like peptide levels were observed in response to propylthiouracil and $\mathrm{T} 4$ treatments in various brain regions involved in mood regulation. Significant effects were measured within $2 \mathrm{~h}$ of T4 injection (Pekary et al. 2006a). Diurnal variations exist in the levels of TRH-like peptides in brain regions involved in mood regulation. TRH-like peptide levels were highly correlated with changes in TRH concentration, within and between brain regions (Pekary et al. 2006b).

\section{TRH-like peptides in other tissues}

High levels of TRH-like peptides occur in the pancreas. pEFPam is the most abundant TRH-like peptide in the pancreas and it was increased 4 times after treatment with valproate. pEFPam inhibits both basal and TRH-stimulated insulin release (Pekary et al. 2006d).

Rat and human mammary gland and the milk of rat, cow, ewe and sow contain neutral TRHimmunoreactive peptides. In a series of patients with breast carcinoma, mammary tumor tissue was shown to contain approximately four times more TRH-like peptides than normal mammary tissue from the same patient, raising the possibility that the TRH-like peptides 
may be implicated in tumor development (Ghilchik et al. 2000).

\section{Conclusion}

TRH-like peptides affect reproductive and endocrine tissues and they are also endogenous neuroprotective and antidepressant-like peptides influencing central nervous system. The recent research is targeted mainly to clarify the mechanism which serves for realisation of biological function of TRH-like peptides in various parts of organism. Ruiz-Alcaraz and Del RioGarcia (2005) were proposed a new mechanism of regulation of hypophyseal-gonadal axis, a negative feedback to the pituitary exerted by the TRH-like peptides (named gonadins) produced in the testis. Cockle et al. (1994) named pEEPam such as fertilizationpromoting peptide because of its function in fertilization. Bílek et al. (2000) suppose that TRH-like peptides can be part of new regulatory mechanism influencing the proliferative ability of prostatic tissues. Pekary et al.
(2005) points to a neuroprotective and antidepressant functioning of TRH-like peptides in brain. Smyth et al. (1999) reveal the presence of TRH and TRH-like peptides in thyroid gland where they may be involved in the regulation of thyroid status. TRH-like peptides was also found in pancreas where they may inhibit insulin release. It can be concluded that TRH-like peptides perform many tasks in the living organism. The mechanism of their action is not yet fully explored, and research should continue in this area.

\section{Conflict of Interest}

There is no conflict of interest.

\section{Acknowledgements}

This paper is dedicated to Prof. MUDr. RNDr. L. Stárka, DrSc., one of the leaders in the area of endocrinology. The work was supported by the grant No. NS/9837-4 of the Internal Grant Agency, Ministry of Health, Czech Republic.

\section{References}

ABRAHAMSSON PA, LILJA H: Partial characterization of a thyroid-stimulating hormone-like peptide in neuroendocrine cells of the human prostate gland. Prostate 14: 71-81, 1989.

ALONSO AD, DI CLERICO J, LI B, CORBO CP, ALANIZ ME, GRUNDKE-IQBAL I, IQBAL K: Phosphorylation of tau at Thr212, Thr231 and Ser262 combined causes neurodegeneration. J Biol Chem 285: 30851-30860, 2010.

BILEK R: TRH-like peptides in prostate gland and other tissues. Physiol Res 49 (Suppl 1): S19-S26, 2000.

BILEK R, BRADBURY AF, SMYTH DG: Synthesis and high-performance liquid chromatographic purification of tritiated thyrotrophin-releasing hormone-like peptides. J Chromatogr B Biomed Appl 656: 115-118, 1994.

BÍLEK R, GKONOS PJ, SOUTOROVÁ M, STÁRKA L, SMYTH DG: The effect of androgens on the concentration of TRH-like peptides in rat prostate. The Thyroid Gland (Merck) 3: 58-67, 1996.

BILEK R, GKONOS PJ, TAVIANINI MA, SMYTH DG, ROOS BA: The thyrotrophin-releasing hormone (TRH)-like peptides in rat prostate are not formed by expression of the TRH gene but are suppressed by thyroid hormone. J Endocrinol 132: 177-184, 1992.

BILEK R, STARKA L: The computer modelling of human TRH receptor, TRH and TRH-like peptides. Physiol Res 54: 141-150, 2005.

BOLER J, ENZMANN F, FOLKERS K, BOWERS CY, SCHALLY AV: The identity of chemical and hormonal properties of the thyrotropin releasing hormone and pyroglutamyl-histidyl-proline amide. Biochem Biophys Res Commun 37: 705-710, 1969.

BURGUS R, DUNN TF, DESIDERIO D, WARD DN, VALE W, GUILLEMIN R: Characterization of ovine hypothalamic hypophysiotropic TSH-releasing factor. Nature 226: 321-325, 1970.

COCKLE SM, AITKEN A, BEG F, MORRELL JM, SMYTH DG: The TRH-related peptide pyroglutamyglutamylprolinamide is present in human semen. FEBS Lett 252: 113-117, 1989a.

COCKLE SM, AITKEN A, BEG F, SMYTH DG: A novel peptide, pyroglutamylglutamylproline amide, in the rabbit prostate complex, structurally related to thyrotrophin-releasing hormone. J Biol Chem 264: 7788-7791, 1989 b. 
COCKLE SM, PRATER GV, THETFORD CR, HAMILTON C, MALONE PR, MUNDY AR: Peptides related to thyrotrophin-releasing hormone (TRH) in human prostate and semen. Biochim Biophys Acta 1227: 60-66, 1994.

CREMADES A, PENAFIEL R, RAUSELL V, DEL RIO-GARCIA J, SMYTH DG: The thyrotropin-releasing hormonelike peptides pGlu-Phe-Pro amide and pGlu-Glu-Pro amide increase plasma triiodothyronine levels in the mouse; the activity is sensitive to testosterone. Eur J Pharmacol 358: 63-67, 1998.

DE MIGUEL M, FERNANDEZ-SANTOS JM, UTRILlA JC, CARRILLO-VICO A, BORRERO J, CONDE E, GUERRERO JM, MARTIN-LACAVE I: Thyrotropin-releasing hormone receptor expression in thyroid follicular cells: a new paracrine role of C-cells? Histol Histopathol 20: 713-718, 2005.

FUKUSUMI S, OGI K, ONDA H, HINUMA S: Distribution of thyrotropin-releasing hormone receptor mRNA in rat peripheral tissues. Regul Pept 57: 115-121, 1995.

GHILCHIK MW, TOBARUELA M, DEL RIO-GARCIA J, SMYTH DG: Characterization of neutral TRH-like peptides in mammary gland, mammary tumors and milk. Biochim Biophys Acta 1475: 55-60, 2000.

GKONOS PJ, KWOK CK, BLOCK NL, ROOS BA: Identification of the human seminal TRH-like peptide pGlu-PhePro-NH2 in normal human prostate. Peptides 15: 1281-1283, 1994.

GREEN CM, COCKLE SM, WATSON PF, FRASER LR: Fertilization promoting peptide, a tripeptide similar to thyrotrophin-releasing hormone, stimulates the capacitation and fertilizing ability of human spermatozoa in vitro. Hum Reprod 11: 830-836, 1996 a.

GREEN CM, COCKLE SM, WATSON PF, FRASER LR: A possible mechanism of action for fertilization promoting peptide, a TRH-related tripeptide that promotes capacitation and fertilizing ability in mammalian spermatozoa. Mol Reprod Dev 45: 244-252, 1996 b.

HINKLE PM, PEKARY AE, SENANAYAKI S, SATTIN A: Role of TRH receptors as possible mediators of analeptic actions of TRH-like peptides. Brain Res 935: 59-64, 2002.

ITADANI H, NAKAMURA T, ITOH J, IWAASA H, KANATANI A, BORKOWSKI J, IHARA M, OHTA M: Cloning and characterization of a new subtype of thyrotropin-releasing hormone receptors. Biochem Biophys Res Commun 250: 68-71, 1998.

IVERSEN E: Pharmacokinetics of thyrotrophin-releasing hormone in patients in different thyroid states. J Endocrinol 128: $153-159,1991$.

KELLY JA, SLATOR GR, O'BOYLE KM: Pharmacologically distinct binding sites in rat brain for [3H]thyrotropinreleasing hormone (TRH) and [3H][3-methyl-histidine(2)]TRH. Biochem Pharmacol 63: 2197-2206, 2002.

KHAN Z, AITKEN A, GARCIA JR, SMYTH DG: Isolation and identification of two neutral thyrotropin releasing hormone-like peptides, pyroglutamylphenylalanineproline amide and pyroglutamylglutamineproline amide, from human seminal fluid. J Biol Chem 267: 7464-7469, 1992.

KHAN Z, SMYTH DG: Isolation and identification of N-terminally extended forms of 5-oxoprolylglutamylprolinamide (Glp-Glu-Pro-NH2), a thyrotropin-releasing-hormone (TRH)-like peptide present in human semen. Eur $J$ Biochem 212: 35-40, 1993.

KOENIG ML, SGARLAT CM, YOURICK DL, LONG JB, MEYERHOFF JL: In vitro neuroprotection against glutamate-induced toxicity by pGlu-Glu-Pro-NH(2) (EEP). Peptides 22: 2091-2097, 2001.

LACKEY DB: Isolation and structural determination of a novel TRH-like tripeptide, pyroGlu-Tyr-Pro amide, from alfalfa. J Biol Chem 267: 17508-17511, 1992.

LINDEN H, DEL RIO GARCIA J, HUBER A, KREIL G, SMYTH D: The TRH-like peptides in rabbit testis are different from the TRH-like peptide in the prostate. FEBS Lett 379: 11-14, 1996.

LLOYD RL, PEKARY AE, SATTIN A, AMUNDSON T: Antidepressant effects of thyrotropin-releasing hormone analogues using a rodent model of depression. Pharmacol Biochem Behav 70: 15-22, 2001.

MORRISON N, DUTHIE SM, BOYD E, EIDNE KA, CONNOR JM: Assignment of the gene encoding the human thyrotropin-releasing hormone receptor to 8q23 by fluorescence in situ hybridization. Hum Genet 93: 716-718, 1994.

NGUYEN V, ZHARIKOVA AD, PROKAI L: Evidence for interplay between thyrotropin-releasing hormone (TRH) and its structural analogue pGlu-Glu-Pro-NH2 ([Glu2]TRH) in the brain: an in vivo microdialysis study. Neurosci Lett 415: 64-67, 2007. 
PEKARY AE, FAULL KF, PAULSON M, LLOYD RL, SATTIN A: TRH-like antidepressant peptide, pyroglutamyltyroslyprolineamide, occurs in rat brain. J Mass Spectrom 40: 1232-1236, 2005.

PEKARY AE, HERSHMAN JM, FRIEDMAN S: Human semen contains thyrotropin releasing hormone (TRH), a TRH-homologous peptide, and TRH-binding substances. J Androl 4: 399-407, 1983.

PEKARY AE, SATTIN A: Regulation of TRH and TRH-related peptides in rat brain by thyroid and steroid hormones. Peptides 22: 1161-1173, 2001.

PEKARY AE, SATTIN A, BLOOD J, FURST S: TRH and TRH-like peptide expression in rat following episodic or continuous corticosterone. Psychoneuroendocrinology 33: 1183-1197, 2008.

PEKARY AE, SATTIN A, STEVENS SA: Rapid modulation of TRH-like peptides in rat brain by thyroid hormones. Peptides 27: 1577-1588, 2006a.

PEKARY AE, SATTIN A, STEVENS SA: Rapid modulation of TRH and TRH-like peptide levels in rat brain and peripheral tissues by corticosterone. Neurochem Int 48: 208-217, 2006c.

PEKARY AE, STEVENS SA, BLOOD JD, SATTIN A: Rapid modulation of TRH and TRH-like peptide release in rat brain, pancreas, and testis by a GSK-3beta inhibitor. Peptides 31: 1083-1093, 2010.

PEKARY AE, STEVENS SA, SATTIN A: Circadian rhythms of TRH-like peptide levels in rat brain. Brain Res 1125: 67-76, 2006b.

PEKARY AE, STEVENS SA, SATTIN A: Valproate and copper accelerate TRH-like peptide synthesis in male rat pancreas and reproductive tissues. Peptides 27: 2901-2911, $2006 \mathrm{~d}$.

PEKARY AE, STEVENS SA, SATTIN A: Lipopolysaccharide modulation of thyrotropin-releasing hormone (TRH) and TRH-like peptide levels in rat brain and endocrine organs. J Mol Neurosci 31: 245-259, 2007.

PROKAI-TATRAI K, TEIXIDO M, NGUYEN V, ZHARIKOVA AD, PROKAI L: A pyridinium-substituted analog of the TRH-like tripeptide pGlu-Glu-Pro-NH2 and its prodrugs as central nervous system agents. Med Chem 1: 141-152, 2005.

PROKAI L, ZHARIKOVA AD: Neuropharmacodynamic evaluation of the centrally active thyrotropin-releasing hormone analogue [Leu2]TRH and its chemical brain-targeting system. Brain Res 952: 268-274, 2002.

RUIZ-ALCARAZ AJ, DEL RIO-GARCIA J: Characterization of a circulating N-extended form of the thyrotropinreleasing hormone-like peptide pGlu-Glu-Pro amide in human plasma. J Clin Endocrinol Metab 88: 60026007, 2003.

RUIZ-ALCARAZ AJ, DEL RIO-GARCIA J: Gonadins, a novel family of glutamyl-tripeptide amides present in the testis with activity in the hypophyseal-gonadal axis. Regul Pept 129: 93-101, 2005.

SATOH T, MORI M: Molecular cloning and posttranslational processing of human preprothyrotropin-releasing hormone (in Japanese). Nippon Rinsho 52: 995-1000, 1994.

SATTIN A, PEKARY AE, BLOOD J: Escitalopram regulates expression of TRH and TRH-like peptides in rat brain and peripheral tissues. Neuroendocrinology 88: 135-146, 2008.

SCALABRINO GA, HOGAN N, O'BOYLE KM, SLATOR GR, GREGG DJ, FITCHETT CM, DRAPER SM, BENNETT GW, HINKLE PM, BAUER K, WILLIAMS CH, TIPTON KF, KELLY JA: Discovery of a dual action first-in-class peptide that mimics and enhances CNS-mediated actions of thyrotropin-releasing hormone. Neuropharmacology 52: 1472-1481, 2007.

SHANAHAN F: A gut reaction: lymphoepithelial communication in the intestine. Science 275: 1897-1898, 1997.

SCHALLY AV, REDDING TW, BOWERS CY, BARRETT JF: Isolation and properties of porcine thyrotropinreleasing hormone. J Biol Chem 244: 4077-4088, 1969.

SCHREIBER V, KMENTOVA V: Effects of methylthiouracil or thyroidectomy on activation of pituitary acid phosphatases in vitro by whole hypothalmic extract. Nature 184 (Suppl 10): 728, 1959.

SCHREIBER V, RYBAK M, ECKERTOVA A, KOCI J, JIRGL V, FRANC Z, KMENTOVA V: Isolation of a hypothalamic peptide with TRF (thyreotrophin releasing factor) activity in vitro. Experientia 18: 338-340, 1962.

SMYTH DG, DEL RIO-GARCIA J, WALLNOFER H, GOGL H, SIMMA W, HUBER A, EMBACHER R, FRASER H, KREIL G: Protirelin (thyrotropin-releasing hormone) in thyroid gland: possible involvement in regulation of thyroid status. Zhongguo Yao Li Xue Bao 20: 289-291, 1999. 
SUN Y, LU X, GERSHENGORN MC: Thyrotropin-releasing hormone receptors - similarities and differences. $J$ Mol Endocrinol 30: 87-97, 2003.

WANG J, WHETSELL M, KLEIN JR: Local hormone networks and intestinal T cell homeostasis. Science 275: 19371939, 1997.

YAMADA M, RADOVICK S, WONDISFORD FE, NAKAYAMA Y, WEINTRAUB BD, WILBER JF: Cloning and structure of human genomic DNA and hypothalamic cDNA encoding human prepro thyrotropin-releasing hormone. Mol Endocrinol 4: 551-556, 1990. 